\title{
LEGAL SANCTIONS TO ENFORCE DESEGREGATION IN THE PUBLIC SCHOOLS: THE CONTEMPT POWER AND THE CIVIL RIGHTS ACTS
}

IMrPLEMENTATION of desegregation in the public schools is a problem that will be solved, at least in part, by resort to the coercive sanctions that the law provides. The history of law enforcement in the United States does not demonstrate that the full use of the more powerful legal weapons necessarily results in obedience, or that it is even advisable to use all available legal force to effect as widespread a social change as desegregation. ${ }^{1}$ But the wisdom of using legal sanctions cannot properly be assessed without knowledge and analysis of what legal force can be mobilized. Since Southern senators can be expected, by means of the filibuster, to prevent the enactment of new legislation specifically designed to enforce desegregation, existing laws and court powers must suffice. The contempt power of the federal courts ${ }^{2}$ and the Federal Civil Rights Acts ${ }^{3}$ appear to afford sanctions which can be used to help eliminate resistance to legally valid attempts to establish and maintain a nondiscriminatory school system. This comment will examine the extent to which these two devices can be so utilized.

\section{The Right to Desegregated Education}

Racial segregation in the public school systems of the forty-eight states and the District of Columbia is now unconstitutional even if Negro and white school children are afforded physical equality in educational facilities. In Brown v. Board of Education ${ }^{4}$ the Supreme Court held that segregation in

1. See Comment, Racial Violence and Civil Rights Law Enforcement, 8 U. CHr. L. Rev. 769 (1951).

2. Early in United States legal history the Supreme Court stated that the federal courts have an inherent and indispensable power to use fines and imprisonment to coerce obedience and to punish for defiance of their orders. E.g., United States v. Hudson, 11 U.S. (7 Cranch) 32, 34 (1812). See also Ex parte Robinson, 86 U.S. (19 Wall.) 505, 510 (1873). This power has been limited by Congress in a number of enactments, but the basic power, especially the power to coerce rather than to punish, has remained as it was in 1812. The most important statutory limitation is 18 U.S.C. $\$ 401$ (1952), which allows a federal court to punish for contempt of its authority only when conduct fits int" three specified categories, one of which is "disobedience to its lawful writ, process, ordcr, rule, decree or command," 18 U.S.C. $\$ 401(3)$ (1952). Whether or not $\$ 401$ is applicable to the court's power over civil contempt is uncertain. See Wright, et al., Civil and Criminal Contempt in the Federal Courts, 17 F.R.D. 167, 169 (1955).

3. 16 STAT. 144 (1870), 42 U.S.C. $\$ 1981$ (1952) ; 14 STAT. 27 (1866), 42 U.S.C. \$ 1982 (1952); 17 StaT. 13 (1871), 42 U.S.C. $\$ 1983$ (1952); 18 Star. 337 (1875), 42 U.S.C. $\$ 1984$ (1952); 12 Stat. 284 (1861), 17 Stat. 13 (1871), 42 U.S.C. \$ 1985 (1952) ; 17 Stat. 15 (1871), 42 U.S.C. $\$ 1986$ (1952) (civil provisions); 18 U.S.C. $\$ \$ 241-42$ (1952) (criminal provisions).

4. 347 U.S. 483 (1954). 
state schools deprives Negro children of their Fourteenth Amendment right to the equal protection of the laws. In a companion case, Bowling v. Sharpe, segregation in the capital's public schools was held to infringe the due process guarantee of the Fifth Amendment. The Court did not promulgate its decree until over a year after it decided that school segregation was unconstitutional, during which time it allowed reargument on the proper formulation of its mandate. ${ }^{B}$ The decree remanded the four cases which had been consolidated in Brown to the district courts in which they originated, with instructions that the district courts require defendant boards of education forthwith to make a prompt and reasonable start towards admitting plaintiffs to the public schools on a nondiscriminatory basis. ${ }^{7}$ If defendants establish that they are making a bonafide attempt to desegregate, the courts are authorized to allow additional time where they find that some delay is justified. The Supreme Court apparently intended to limit the discretion of the district courts, for it listed the factors which the lower courts could take into consideration in deciding on requested extensions. They consist of both problems of administration such as the physical condition of the plant, the school transportation system, and necessary revision of local laws and regulations, and the adequacy of any plans proposed by defendants. ${ }^{8}$

\section{The Nature of the Right}

The nature of a student's right to desegregated education is not clear. The only certain aspect of the right is that its deprivation may be remedied by equitable relief in the manner prescribed by the Brozen decree. Thus, all Negro children in the South have both the right to require a district court to

5. 347 U.S. 497 (1954).

6. The Supreme Court decree for both the state and District of Columbia case's is found in Brown v. Board of Education, 349 U.S. 294 (1955). The state cases came from separate school districts in Kansas, South Carolina, Virginia and Delaware.

7. Ibid. See Jackson v. Rawdon, 135 F. Supp. 936 (N.D. Tex. 1955) (commencement by school district of work on plans for integration held to constitute a prompt and reasonable start).

8. Erown v. Board of Education, 349 U.S. 294 (1955). See note 20 infra for relevant excerpts from the decree.

Lower court responses to the Brozen decision and decree have taken four forms: (1) Designating a date for final integration, Willis v. Walker, 136 F. Supp. 177 (W.D. Ky. 1955) ; (2) Adopting a plan for gradual integration submitted by the school board, Brown v. Eoard of Education, Civil No. T-316, D. Kan., Oct. 28, 1955; (3) Issuing a decree ordering integration after time for "necessary" arrangements has elapsed, Briggs v. Elliott, 132 F. Supp. 776 (E.D.S.C. 1955), Davis v. County School Bd., Civil No. 1333, E.D. Va., July 18,1955 ; (4) Ordering only a start towards integration, and deferring consideration of further orders until the school board has had time to solve local problems, Matthews $v$. Launius, 134 F. Supp. (W.D. Ark. 1955) ; cf. Jackson v. Rawdon, 135 F. Supp. 936 (N.D. Tex. 1955).

The decrees in Briggs and Davis ordered: "[T] hereby restrained and enjoined from refusing on account of race (or color) to admit to any school under their supervision any child qualified to enter such school, from and after 
order their local school boards to make a prompt and reasonable start towards integration and the right to have the court's discretion in allowing delay limited in the manner stipulated by the Brown decree. But defining the right to integrated education will prove difficult whenever plaintiffs seek to remedy deprivations of this right in an action at law. The civil provisions of the Civil Rights Acts entitle a plaintiff to money damages for a deprivation of his Fourteenth Amendment rights. ${ }^{9}$

There are three possible interpretations of the "right" which the Brozon decision recognizes. First, an immediate right to attend an integrated school may have been established. Under this view a Negro child denied access to an integrated school could inmediately sue for damages even though the granting of equitable relief ordering his admission could be postponed in the manner outlined in the Brown decree. Secondly, the immediate right recognized by the Brown decision may be only the right to have a local school board make a prompt and reasonable start towards integration; the right to enter an integrated school would mature only when there had elapsed sufficient time for the elimination of the factors which the Brozun decree indicated might justify postponing complete desegregation. This theory would require a plaintiff seeking damages to prove that the school board's delay was not justified. ${ }^{10}$ Finally, it could be contended that by investing the district courts with quasiadministrative authority over the implementation of desegregation, the Supreme Court recognized an immediate right only to set the district court machinery in motion on the course delimited by the Brown decree. Whenever a district court orders a school board to take specific steps towards integration, a Negro child would acquire a right to the benefit of what has been ordered. ${ }^{11}$ Under this view the right to attend an integrated school would not mature until the date actually set by a district court for complete desegregation.

Of these three possible interpretations, the view recognizing an immediate right to an integrated education is the most consistent with traditional precepts of constitutional law, but this interpretation runs counter to the spirit of the Court's approach to the problem and is thoroughly unrealistic. Generally, when the Supreme Court holds some state action to violate the Fourteenth Amendment, all persons have an immediate right to invoke the Civil Rights Acts and sue for damages for deprivations caused by any continued unconsti-

such time as they (the defendants) may have made the necessary arrangements for admission of children to such school on a non-discriminatory basis with all deliberate speed as required by the decision of the Supreme Court in this cause." Brown v. Board of Education, supra; Davis v. County School Bd., supra (words in parentheses are used only in Davis).

9. See text at notes 111-53 infra.

10. In these damage suits the plaintiff can also request a decree ordering complete integration. Though the legal right may have matured, equity will still not order integration until the permissable time period, measured from the date of a decree, has elapsed.

11. This same result should also follow under the second interpretation, whenever the plaintiff elects to obtain a decree. 
tutional action. ${ }^{12}$ But it seems unlikely that the Supreme Court had any intention of subjecting school boards to suits for damages before they had a reasonable time to eliminate a system of segregated schools. ${ }^{13}$ Even if this view were to prevail, Negro plaintiffs would be well-advised to refrain from exploiting it. If courts were confronted with suits for damages before school boards had time to integrate, judicial reluctance to uphold such damage claims might well prompt interpretations of the Civil Rights Acts which would drastically restrict the utility of these statutes in more reasonable situations. ${ }^{14}$

As between the two interpretations recognizing that the right to attend an integrated school may not be immediate, the view that the right will mature after a certain period of time has elapsed, irrespective of whether a decree is obtained, seems preferable. Both interpretations agree that the right to an integrated education is unique among Fourteenth Amendment rights in that it was not mature on the day it was recognized. This departure from traditional constitutional interpretation may be justified by the complexities which the Court has recognized will attend the process of desegregating the entire school system of any particular district. Though earlier education decisions declared that the right of a Negro to attend a white graduate school was immediate, these decisions were concerned with the right to attend a school that was already in operation. ${ }^{15}$ The establishment of a new system of schools was not required. But the notion that the delayed right matures only after a district court decree orders complete integration seems unnecessarily restrictive. Normally, vindication of rights does not depend on the securing of a decree ordering the recognition of those rights. Such an interpretation should not be adopted in the absence of a clear mandate in the Brown decision.

In practice the theoretical differences between these two positions will generally prove to be of little consequence. Under the theory of a right independent of a decree, the plaintiff may sue for damages where the school board violates the immediate right to a prompt and reasonable start made towards integration. But school boards will usually be able to defeat these suits by demonstrating that the appointment of committees to "study" the problem constitutes a "start."10 A real difference might sometimes develop, however, when a plaintiff sues for denial of his delayed right to attend an integrated school. Very likely district courts faced with such damage suits would often find that a sufficient time period had not elapsed and hence deny that the right had matured. But if a considerable period of time has elapsed, it will be almost

12. E.g., McDonald v. Key, 224 F.2d 608 (10th Cir. 1955); Flemming v. South Carolina Elec. \& Gas Co., 224 F.2d 752 (4th Cir. 1955).

13. See text at note 15 infra.

14. For a discussion of the doctrines which courts may use to restrict the application of the Civil Rights Acts, see text at notes 135-53 infra.

15. "It is fundamental that these cases concern rights which are personal and present." Sweatt v. Painter, 339 U.S. 629, 635 (1950) ; McLaurin v. Oklahoma State Regents, 339 U.S. 637 (1950); see State ex rol. Hawkins v. Board of Control, 24 U.S.L. WEEK 4135 (U.S. March 12, 1956).

16. Jackson v. Rawdon, 135 F. Supp. 936 (N.D. Tex. 1955). 
impossible for district courts to find that the factors specified in the Brown decree could justify such a delay. ${ }^{17}$ Nevertheless, Negro students who want to attend an integrated school will probably achieve that result primarily by seeking decrees ordering integration. Most of the damage suits brought in the near future for denial of the right to attend an integrated school will probably fail, since courts will be reluctant to say that the requisite time period has elapsed when this determination would result in the imposition of damages. In denying damages, these courts will probably grant additional time to integrate; so the result will often be substantially the same as if the plaintiffs had been content to seek only equitable relief in the first instance.

In Northern communities which for many years have maintained integrated school systems and in Southern communities which voluntarily convert to such systems, a student's right to an integrated education should be immediate under any theory. Brozen recognizes a delayed right to attend an integrated school only in districts where certain factors justify delay in changing from a segregated to a desegregated system. But in districts where changes in the school system are unnecessary or where school boards concede that no factors justify delay, there is no need for gradualism. In such a school district impairment of the right to an integrated education might take the form of discriminatory practices by individual school officials, attempts by private persons to interfere with an integrated system, or an attempt by the governing political unit to disestablish the integrated system. As soon as these deprivations are sustained or threatened, they can be remedied by the Civil Rights Acts. ${ }^{13}$

17. The possibility that sufficiently long delay would warrant the imposition of damages against defendant school boards, even though no decree had informed the boards what time period was permissible, might lead to an anomalous result. School boards, not knowing at what point in time they might become liable for damages to all Negro school children in their districts, might find it advisable to seek declaratory judgments to determine what period of time the local district court will allow. See 28 U.S.C. \$ 2202 (1952), Aetna Life Ins. Co. v. Haworth, 300 U.S. 216, 244 (1937). In such suits the courts might not only determine the time period but also issue a decree ordering integration within the period. Cf. Petersine Incubator Co. v. Bundy Incubator Co., 135 F.2d 580 (6th Cir.), appeal dismissed, 320 U.S. 805 (1943) (in suit for a declaratory judgment invalidating a patent, court declared patent valid, enjoined plaintiff from further infringement, and ordered an accounting). Thus, the numerous lawsuits which it is now anticipated will be brought by Negro students to obtain decrees, see text at notes 31-33 infra, may in some areas be brought by school boards.

18. See note 3 supra; text at notes $92-156$ infra.

Judicial consideration of the nature of a student's right to a desegregated education has thus far been confined to the problem of equitable relief. For example, the Delaware Supreme Court, writing during the period between the Brozwn decision and decree, observed: "The effect of the decision in the Segregation Cases seems to us to be this: The Supreme Court of the United States has determined a right to exist, but has not yet determined the remedy. Until that remedy shall be fixed, the right is not a present enforceable one." Steiner v. Simmons, 111 A.2d 574, 579 (De1. 1955). It should be noted that "the remedy" requested in Brozm was equitable relief. Therefore, the conclusion that "the right" is not a "present enforceable one" does not necessarily follow where plaintiffs seek damages under the analysis outlined above. 


\section{Desegregation Is To Take Effect in the Face of Southern Resistance}

The opinion and decree in Brown demonstrate that the Court did not intend to let the South proceed towards desegregation at its own speed. Thus coercive sanctions generally available for remedying deprivations of constitutional rights and enforcing decrees which restrain the deprivation of those rights may be used, if necessary. Although in argument the Court did consider the possibility that an attempt to desegregate the schools would encounter extreme resistance, ${ }^{10}$ the wording of its decree indicates that the Court will not tolerate the postponement of school integration until Southern opinion is ready for the change. ${ }^{20}$ Desegregation is to be effected even in the face of Southern resistance. The only suggestion that the district courts may consider public resistance, in proceedings for additional time to complete integration, is the state-

19. See, c.g., Brief for Appellees on Reargument, Briggs v. Elliot, Oct. Term, 1953, pp. 77-79, dccidcd sub nom. Brown v. Board of Education, 347 U.S. 483 (1954), 349 U.S. 294 (1955). See Note, 64 YALE L.J. 124, 133-34 (1954), for analysis of the propriety of giving weight to such considerations.

20. The importance of this question justifies a fairly full reprint of the court's decree:

"These cases were decided on May 17, 1954. The opinions of that date, declaring the fundamental principle that racial discrimination in public education is unconstitutional, are incorporated herein by reference. All provisions of federal, state or local law requiring or permitting such discrimination must yield to this principle.

"....

"Full implementation of these constitutional principles may require solution of varied local school problems. School authorities have the primary responsibility for ... solving these problems; courts will have to consider whether the action of the school authorities constitutes good faith implementation of governing constitutional principlcs. Because of their proximity to local conditions and the possible need for further hearings, the courts which originally heard these cases can best perform this judicial appraisal. Accordingly we believe it appropriate to remand the cases to those courts.

"In fashioning and effectuating the decrees the courts will be guided by equitable principles. Traditionally, equity has been characterized by a practical flexibility in shaping its remedies and by a facility for adjusting and reconciling public and private needs. At stake is the personal interest of the plaintiffs in admission to public schools as soon as practicable on a nondiscriminatory basis. To effectuate this interest may call for elimination of a variety of obstacles in making the transition.... Courts of equity may properly take into account the public interest in the elimination of a variety of such obstacles in a systematic and effective manner. But it should go without saying that the vitality of these constitutional principles can not be allowed to yield simply because of disagreement with them.

"While giving weight to these public and private considerations, the courts will require that the defendants make a prompt and reasonable start toward full compliance with our May 17, 1954 ruling. Once such a start has been made, the courts may find that additional time is necessary to carry out the ruling in an effective manner. The burden rests upon the defendants to establish that such time is necessary in the public interest and is consistent with good faith compliance at the earliest possible date. To that end, the courts may consider problems related to administration, arising from the physical condition of the school plant, the school transportation system, personnel, revision of school districts and attendance areas into compact units to achieve a system of determining admission to the public 
ment that courts of equity may take into account the public interest in the systematic and effective elimination of the "variety of obstacles" to the transition. 21 The possible implication that public resistance is one of such "obstacles" seems to be negatived by the Court's specific enumeration of the factors which the district courts may consider in determining whether to allow delay. Public resistance was not mentioned. ${ }^{22}$

Nevertheless, implementation of the principles promulgated in Brown and Bowling may be greatly delayed, for a substantial amount of resistance-direct and indirect, spontaneous and planned-is to be expected whenever there is an attempt to order integration. ${ }^{23}$ In communities which began desegregation before the promulgation of the decree, opposition has already arisen. The Milford incident in Delaware is a graphic example of intimidation by community action which can force a school board to abandon its attempt to admit Negroes into white schools. ${ }^{24}$ In many of the states which are awaiting specific decrees, legislators, public officials and community leaders have been formulating elaborate plans for evading the expected attempt to enforce desegregation. ${ }^{25}$ At no other time since the enactment of the post-Civil War amendments has the South had to face such an enormous social change imposed under national law. At no other time since the early days of the Ku Klux Klan has the Southern white community been mobilized in as comprehensive a program to deny Negroes their constitutional rights.

schools on a nonracial basis, and revision of local laws and regulations which may be necessary in solving the foregoing problems. They will also consider the adequacy of any plans the defendants may propose to meet these problems and effectuate a transition to a racially nondiscriminatory school system."

Brown v. Board of Education, 349 U.S. 294, 298-301 (1955).

21. Id. at 300 .

22. Id. at 300-01. That the enumeration of specific factors comes after the statement of a "variety of obstacles," further suggests that the enumeration qualifies the broad phrase used by the Court. This interpretation of Brown is consistent with the construction given the decree in Willis v. Walker, 136 F. Supp. 177 (W.D. Ky. 1955). The court ordered school officials to integrate Adair County elementary schools completely by September 1956, and to integrate the Adair County high school by February 1956 . Only administrative difficulties were considered by the court in setting the time limits.

23. In the states which have taken positive steps towards integration, little violence has taken place although organized resistance and loud protest is abundant in many areas. However, school districts with a substantial percentage of Negro students have made little attempt to integrate.

The most comprehensive and accurate report of general and legal news concerning desegregation can be found in the monthly publications of Southern School News, published by the Southern Education Reporting Service, P.O. Box 6156, Acklen Station, Nashville, Tennessee. And see 1 Race Relatrons L. Rep. passim (1956).

24. See N.Y. Times, Oct. 1, 1954, § 1, p. 21, col. 1. See also id., May 16, 1955, § 1, p. 18, col. 2, for a report of the election in the Milford school district of a board of education pledged to continue segregation.

25. U.S. News \& World Report, May 28, 1954, pp. 21-24; N.Y. Times, Dec. 9, 1955, p. 24 cols. $2-4$ (report of speech of Eugene Cook, Attorney General of Georgia). Sec Southern School News, supra note 23, for current reports of plans for circumvention. 
Southern resistance will undoubtedly assume diverse forms. ${ }^{20}$ While resistance may initially take place in the refusal of certain district court judges to follow the letter or spirit of the directions in a Brown-type decree, most of the resistance will probably arise in opposition to the district court decrees formulated in accordance with the Supreme Court's orders. ${ }^{27}$

Modes of resistance will include refusal to comply with district court orders; violence and threats of violence directed by white students, their parents and other adults, with and without the aid or acquiescence of school and governmental officials, against Negro students, their parents and leaders as well as against boards of education, public officials and white persons who accept and attempt to implement desegregation; strikes by school children and teachers; economic coercion-the use by employers, creditors and banks of their power to control the economic security of others to coerce Negroes and other persons into accepting segregation $;^{28}$ segregation within a nominally interracial school; and legislative circumvention such as gerrymandering, abolition of public schools and public financing of private segregated schools, withdrawal of state financial support to schools which do desegregate, authorization of individual assignments of students to particular schools in accordance with the discretion of the school board or with ostensibly nonracial classifications which in fact permit assignments on the basis of race, and institution of a complicated system

26. Recent legal literature is already replete with discussion of some forms of resistance and with predictions of a "generation of lawsuits." See, e.g., Leflar \& Davis, Segregation in the Public Schools-1953, 67 HARv. L. Rev. 377 (1954); Nicholson, The Legal Standing of the South's School Resistance Proposals, 7 S.C.L.Q. 1 (1954); Winter, Mississippi's Legislative Approach to the School Segregation Problem, 26 Miss. L.J. 165 (1955); Roche, Plessy v. Ferguson: Requicscat in Pace? 103 U. PA. L. Rev. 44 (1954); Sutherland, Segregation by Race in Public Schools-Retrospect and Prospect, 20 LAw \& Contensp. PRoв. 169 (1955).

27. For an illustration of resistance to integration voluntarily instituted by a local school board, see Hoxie School District No. 46 v. Brewer, 135 F. Supp. 296 (E.D. Ark. 1955), temporary injunction made permancut, 24 U.S.L. WeEk 2323 (E.D. Ark. Jan. 9, 1956). After the Brown decree, on its own volition, Hoxie School District No. 46 in Arkansas ordered its schools to open in July 1955 on an integrated basis. Pupils and their parents peacefully complied for about three weeks when defendants, including members of an association called White America, Inc., started a campaign of opposition to the school board action, which culminated in a mass meeting marked by incendiary speeches and threats of violence. The school board, alleging that the intimidation had caused attendance to decline and that they were thus forced to suspend school sessions, obtained a district court injunction prohibiting certain named defendants, their agents, and those in active concert, from atterngting to trespass or picket on property of the school district, from interfering with the lawful administration of the school district or from intimidating, threatening or attempting to harm plaintiffs or cause them to violate the United States Constitution and laws of the United States in regard to their official duties. Since the school board rather than a student sued for an injunction, the district court's holding that it had jurisdiction is questionable; but even if it erred in this respect, the same result may be obtained as long as a suit is initially brought on behalf of an aggrieved student. 28 U.S.C. $\S 1343(3)$ (1952).

28. See U.S. News \& World Report, Oct. 29, 1954, pp. 29-30. 
of administrative review of pupil assignments which is designed to delay redress of discrimination. ${ }^{29}$

It is commonly believed that the South will gain enormous delays by inaugurating evasive programs. But such delays are not inevitable. When, in the face of a desegregation decree, defendant school board members participate in some type of evasive action which the court invalidates, plaintiffs can later argue that any right to additional time to complete integration has been forfeited. Brown stated that the district courts would be sitting as courts of equity in determining whether to extend the period for compliance. One who has attempted to evade a court's mandate cannot come into that very court whose mandate he has violated and ask for equitable relief. He should be barred by the well-established doctrine that equity will not aid a party with unclean hands. ${ }^{30}$

An unavoidable delay in achieving integration in all schools results from the need to institute separate law suits against each school board which refuses to integrate, since district court decrees ordering desegregation bind only defendants in a particular suit. ${ }^{31}$ If the district courts fail to issue such decrees, plaintiffs can obtain them by appeal to the courts of appeals, or if necessary the Supreme Court. Once Negro plaintiffs can show racial separation in a school system, district and appellate courts will find it difficult to refuse to promulgate Brown-type decrees. ${ }^{32}$ And as in Brown, suits from a number of district courts can be consolidated if an appellate court permits. ${ }^{33}$

\section{The Contempt Power}

The broad contempt powers of the federal courts will be available to reach many of the more serious and tenacious forms of interference. In the centers of greatest resistance federal court decrees will probably be necessary in order to start integration. Once such decrees are obtained, the contempt power can be invoked to combat disobedience and defiance. ${ }^{34}$

29. A summary of the legislation designed to circumvent federally imposed integration, which has been enacted in the eight states of the deep South, is found in Southern School News, Feb. 1956, p. 2.

30. See McClintock, EQuity \$ 26 (1948).

31. 1 FrEEAIAN, JudGMENTS $\$ 407$ (1925). In Brown the defendants in the consolidated suits were school board members of individual school districts in Kansas, South Carolina, Delaware, Virginia and the District of Columbia. Other school boards are not in privity with these defendants. But since these were class actions, Brown v. Board of Education, 347 U.S. 483, 495 (1954), defendant school boards in their respective school districts must give the benefits of the district court decree to all school children who are similarly situated to the named plaintiffs. See, e.g., Bryce v. Byrd, 201 F.2d 664 (5th Cir. 1953) ; Holmes v. City of Atlanta, 124 F. Supp. 290 (N.D. Ga. 1954).

32. See note 20 supra.

33. Brown v. Board of Education, 347 U.S. 483 (1954); see, e.g., Sup. Cr. RulE 43(5). If a number of such actions are instituted in the same judicial district, the district court may order a consolidation to determine common questions of law. FEv. R. Crv. P. 42(a).

34. 18 U.S.C. $\$ 401(3)$ (1952). See, e.g., McComb v. Jacksonville Paper Co., 336 U.S. 187, 193 (1949); United States v. United Mine Workers, 330 U.S. 258, 303-05 (1947); Union Tool Co. v. Wilson, 259 U.S. 107 (1922). 
The two types of contempt proceedings-civil and criminal-have different substantive and procedural rules which will determine their utility. ${ }^{35}$ When the proceeding is solely to aid the successful litigant who secured a decree, it is deemed in civil contempt; ${ }^{30}$ when the court's purpose is to vindicate its authority, the proceeding is in criminal contempt. ${ }^{37}$ Only the court or a United States attorney may institute criminal contempt proceedings, but the court often appoints the plaintiff's attorney to prosecute the action. ${ }^{38}$ Civil contempt proceedings are usually directed against only persons bound by the decree. They include named defendants, their agents and employees, and persons in active concert with them who have actual notice of the decree. ${ }^{39}$ Both persons bound and any others who have actual notice of the decree can be made defendants in a criminal contempt proceeding. ${ }^{40}$ Defendants in a civil contempt suit have no right to a jury trial, 41 nor in a criminal contempt case ${ }^{42}$ unless the "act or thing done or omitted" also constitutes a crime under a federal or state

35. See Gompers v. Bucks Stove \& Range Co., 221 U.S. 418, 444 (1911) ; Comment, Cizil and Criminal Contents in the Federal Coutrts, 57 YALE L.J. 83 (1947); Moskovitz, Contompt of hinunctions, Civil and Criminal, 43 Colunr. L. Rev. 780 (1943); Wright, et al., supra note 2 .

36. E.g., McCrone v. United States, 307 U.S. 61 (1939) ; Lamb v. Cramer, 285 U.S. 217 (1932); Gompers v. Bucks Stove \& Range Co., supra note 35, at 441.

37. E.g., United States v. United Mine Workers, 330 U.S. 258, 302 (1947) ; Gompers v. Bucks Stove \& Range Co., 221 U.S. 418, 441 (1911); In re Reese, 107 Fed. 942 (8th Cir. 1901); In $r e$ Rice, 181 Fed. 217, 220 (C.C.M.D. Ala. 1910).

38. "A criminal contempt ... shall be prosecuted on notice.... The notice shall be given orally by the judge in open court in the presence of the defendant or, on application of a United States attorney or of an attorney appointed by that court for that purpose, by an order to show cause or an order of arrest. ..." Fen. R. CRIMr. P. 42(b). See United States $e x$ rel. Brown v. Lederer, 140 F.2d 136, 138 (7th Cir. 1942) ; Western Fruit Growers, Inc. v. Gotfried, 136 F.2d 98, 100-01 (9th Cir. 1943) ; Wright, et al., supra note 2, at 172.

39. FED. R. Crv. P. 65(d). See, e.g., Wilson v. United States, 221 U.S. 361, 376-77 (1911) ; Commissioners v. Sellew, 99 U.S. 624, 627 (1878) ; cf. Walling v. James V. Reuter, Inc., 321 U.S. 671,674 (1944) ; Moskovitz, supra note 35, at 813.

40. E.g., Bessette v. W. B. Conkey Co., 194 U.S. 324, 329-30 (1904) ; United States v. Debs, 64 Fed. 724 (C.C.N.D. IIl. 1894) ; aff'd sub nom. In re Debs, 158 U.S. 564 (1895); Kelton v. United States, 294 Fed. 491 (3d Cir. 1923). Courts do not often cite persons not named in the order for civil contempt, but there is no reluctance to cite persons not named for criminal contempt if defiance of the court's authority is shown. E.g., United Statcs v. Shipp, 203 U.S. 563 (1906), United States v. Debs, supra; Kelton v. United States, supra. See Note, 46 Harv. L. Rev. 1311 (1933).

41. E.g., Mifchaelson v. United States ex rel. Chicago, St. P., M. \& O. Ry., 266 U.S. 42, 65 (1924) (dictum); United States v. Onan, 190 F.2d 1, 9 (8th Cir.), cert. denied, 342 U.S. 869 (1951) ; Odell v. Bausch \& Lomb Optical Co., 91 F.2d 359, 361 (7th Cir. 1937); Marcus v. Pennsylvania Trust Co., 23 F.2d 303, 305 (3d Cir. 1927).

It has been suggested that 18 U.S.C. $\$ 3692$ (1952), formerly 29 U.S.C. $\$ 111$ (1940), gives the right to a jury trial to defendants in a civil contempt suit which arises out of violation of an injunction issued under the federal labor laws. Wright, ct al., supra note 2, at 174; Comment, 57 YALE L.J. 83, 95 (1947). However, the provision has never been held applicable to civil contempt; it has, indeed, been incorporated into Title 18 of the United States Code, which is entitled "Crimes and Criminal Procedure."

42. E.g., In $r e$ Debs, 158 U.S. 564, 595 (1895) ; Eilenbecker v. District Court, 134 U.S. 31,39 (1890); Maynard v. United States, 23 F.2d 141 (D.C. Cir. 1927). 
statute and is committed outside the presence of the court. ${ }^{43}$ In civil contempt, plaintiff must prove defendant's resistance by clear and convincing evidence, 44 and the defendant's good faith or willfulness is immaterial. ${ }^{45}$ Guilt in criminal contempt must be proved beyond a reasonable doubt, and willful disobedience must be established. ${ }^{40}$ Although a defendant may be prosecuted for criminal and civil contempt in the same proceeding, the criminal aspect governs the applicable procedural rules and safeguards. ${ }^{47}$ And where the proceeding is in criminal contempt, reversal of the decree which has been violated will not bar the contempt prosecution. . $^{48}$

Civil contempt sanctions are remedial, and include both compensatory fines and conditional fines or imprisonment. ${ }^{49} \mathrm{~A}$ defendant can relieve himself from

43. 18 U.S.C. \& 3691 (1952), Michaelson v. United States e.r rel. Chicago, St. P., M. \& O. Ry., 266 U.S. 42, 65 (1924). Section 3691 by its terms is inapplicable to contcmpts committed in disobedience of any lawful order entered in a suit prosecuted in the name of, or on behalf of, the United States. Although it has been suggested that $\$ 3691$ was designed to grant jury trial rights in civil as well as criminal contempt proceedings when the contemptrous conduct violated a state or federal statute, Comment, 57 YALE L.J. 83, 94 (1947), thus far the courts have held the statute applies only to criminal contempt. Michaelson v. United States $e x$ rel. Chicago, St. P., M. \& O. Ry., supra at 65; United States v. Onan, 190 F.2d 1, 9 (8th Cir. 1951) ; Marcus v. Pennsylvania Trust Co., 23 F.2d 303, 305 (3d Cir. 1927). However, a defendant in a criminal contempt suit has a right to a jury trial "in any case in which an act of Congress provides." FED. R. CRIM. P. 42 (b). The statutes specifically giving jury trial rights in criminal contempt proceedings are listcd in note 3 to rule 42, Notes of Advisory Committee on Rules, FED. R. CRIM. P. 42, is U.S.C.A. $\$ 3001$ (1951).

44. E.g., Fox v. Capital Co., 96 F.2d 684, 686 (3d Cir. 1938); Telling v. BellowsClaude Neon Co., 77 F.2d 584 (6th Cir. 1935); Hanly v. Pacific Live Stock Co., 234 Fed. 522, 531 (9th Cir. 1916).

45. E.g., McComb v. Jacksonville Paper Co., 336 U.S. 187, 191 (1948); West Texas Util. Co. v. NLRB, 206 F.2d 442, 448 (D.C. Cir.), cert. denied, 341 U.S. 939 (1953); Morse-Starret Products Co. v. Steccone, 205 F.2d 244, 248 (9th Cir. 1953); NLRB v. Whittier Mills Co., 123 F.2d 725, 727 (5th Cir. 1941) ; Lustgarten v. Felt \& Tarrant Mffg. Co., 92 F.2d 277 (3d Cir. 1937) ; Evans v. International Typographical Union, 81 F. Supp. 675 (S.D. Ind. 1948). See Note, 48 MICH. L. Rev. 860 (1950).

46. See United States v. United Mine Workers, 330 U.S. 258, 303 (1947) (willful disobedience); Gompers v. Bucks Stove \& Range Co., 221 U.S. 418, 444 (1911) (proof beyond a reasonable doubt); United States ex rel. Porter v. Kroger Grocery \& Baking Co., 163 F.2d 168 (7th Cir. 1947) (defendant successfully avoided criminal contempt sanction because there was no substantial evidence that he willfully and knowingly violated an injunction secured by the $O P A$ ).

47. Penfield Co. v. SEC, 330 U.S. 585, 591 (1947) ; United States v. United Mine Workers, supra note 46, at 300-01; Kreplik v. Couch Patents Co., 190 Fed. 565, $572-73$ (1st Cir. 1911).

"The fact however that the two forms of contempt may be joined in the same proceeding and a judgment rendered appropriate to each form furnishes no support for the proposition that a judgment for civil contempt can be supported by a proceeding which was initiated and carried through solely as a criminal contempt." Tobin v. Pielet, 186 F.2d 886,890 (7th Cir. 1951).

48. United States v. United Mine Workers, 330 U.S. 258, 294 (1947).

49. See, e.g., Penfield Co. v. SEC, 330 U.S. 585 (1947) (conditional imprisonment); United States v. United Mine Workers, 330 U.S. 258, 304-05 (1947) (conditional fine); 
these conditional penalties by complying with the decree. Punitive fines or fixed terms of imprisonment are the usual sanctions in a criminal contempt proceeding, ${ }^{50}$ but conditional penalties have on occasion been imposed. ${ }^{51}$ If the act of criminal contempt also constitutes a state or federal crime, punishment is limited to a $\$ 1,000$ fine or six months imprisonment. ${ }^{52}$ Although the court whose order was violated has absolute discretion in withholding punishment for criminal contempt, a plaintiff's right to remedial relief in a civil contempt proceeding is not entirely dependent on the court's exercise of discretion. ${ }^{53}$ Tort immunity of public officials has not prevented the imposition of civil contempt sanctions in the form of compensatory fines payable to the aggrieved party. Contempt proceedings are considered sui generis so that the imposition of compensatory fines, despite its similarity to a verdict in damages, is not the "tort liability" from which some officials are immune. Furthermore, the judicial power necessary to enforce court orders and command respect overrides the policy supporting the immunity doctrine.

Virtually all members of the educational hierarchy may be cited for contempt if they directly interfere with district court decrees ordering integration. Civil contempt sanctions may be imposed upon all persons named in the decree

Gompers v. Bucks Stove \& Range Co., 221 U.S. 418, $441-42$ (1911); West Texas Util. Co. v. NLRB, 206 F.2d 442, 449 (D.C. Cir.), cert. denied, 341 U.S. 939 (1953) (conditional fine) ; Sauber v. Whetstone, 199 F.2d 520 (7th Cir. 1952) (conditional commitment); In re Nevett, 117 Fed. 448, 461 (8th Cir. 1902) (conditional commitment of county court judges to coerce obedience to federal district court mandamus).

The alternative sanctions of civil contempt afford flexibility in enforcement. Compare Woods v. O'Brien, 78 F. Supp. 221 (D.C. Mass. 1948), with United States v. United Mine Workers, supra. In Woods the landlady of a boardinghouse was enjoined by the district court in a suit by the housing expediter on behalf of one of her elderly roomers, to clean his room periodically. Upon her refusal to do so she was adjudged in civil contempt and fined fifty dollars, five dollars of which was to compensate the lodger for his injury and forty-five dollars conditional on the landlady's future continuous obedience. In United Winc Workers $\$ 2,800,000$ of the contempt fine imposed was conditional on compliance with the restraining order.

50. Penfield Co. v. SEC, 330 U.S. 585, 593 (1947); United States v. United Mine Workers, stupra note 49 ( $\$ 700,000$ punitive fine) ; Moore v. United States, 150 F.2d 323 (10th Cir.), cert. denicd, 326 U.S. 740 (1945) ( $\$ 5,000$ punitive fine); Rapp v. United States, 146 F.2d 548 (9th Cir. 1944) (thirty-day jail sentence); In re Reese, 107 Fed. 942 (Sth Cir. 1901) (three-month prison term).

51. E.g., Application of Patterson, 125 F. Supp. 881, 887 (S.D.N.Y. 1954), aff'd, 219 F.2d 659 (2d Cir. 1955) (ninety-day jail sentence conditional on compliance).

52. 18 U.S.C. $\S 402$ (1952). But the third paragraph of $\S 402$ makes this limitation inapplicable both to contempts committed in the presence of the court (or so near thereto as to obstruct the administration of justice), and to contempts committed in disobedience to judicial orders entered in any suit brought in the name of or on behalf of the United States.

53. In reversing a refusal by the district court to find a party in civil contempt for violation of the district court decree, the Court in McComb v. Jacksonville Paper Co., 336 U.S. 187, 191 (1949), said: "[T] he grant or withholding of remedial relief [in civil contempt] is not wholly discretionary with the judge..." See also Union Tool Co. v. Wilson, 259 U.S. 107, 112 (1922); Parker v. United States, 153 F.2d 66, 70 (1st Cir. 1946). 
and their subordinates through whom the court's commands must ultimately be implemented. ${ }^{54}$ The district court decrees may name only the defendant boards of education, or they may specify the various classes of school officials which are to carry out their mandates. Knowing acquiescence in the disobedience of subordinates is civil contempt, ${ }^{55}$ and a party has been held liable in civil contempt for the disobedience of his subordinates even when he had no knowledge of their wrongful acts. ${ }^{56}$ Whether or not school boards order integration to proceed, teachers and administrative officials are subject to a civil contempt suit if they fail to act. ${ }^{57}$ Subordinates cannot immunize themselves from civil contempt by claiming that they were obligated to obey their superiors. ${ }^{\text {bs }}$ If resistance by these parties is violent or flagrant, the court may choose to prosecute for criminal rather than civil contempt, or it may allow a mixed proceeding. ${ }^{59}$

54. "Not only is such an injunction [restraining the corporation and those associated with it] enforcible by contempt proceedings against the corporation, its agents and officers and those individuals associated with it in the conduct of business . . . but it may also in appropriate circumstances, be enforced against those to whom the business may have been transferred, whether as a means of evading the judgment or for other reasons." Walling v. James V. Reuter, Inc., 321 U.S. 671, 674 (1944); see Wilson v. United States, 221 U.S. 361,376 (1911) (president of corporation committed for civil contempt for failure to obey order addressed to corporation); Reliance Mffg. Co. v. NLRB, 143 F.2d 761 (7th Cir. 1944) (corporation, its agents and officers, including some of its supervisory employces, held in contempt for violating restraining order) ; NLRB v. Rath Packing Co., 130 F.2d 540 (8th Cir. 1942) ; L. E. Waterman Co. v. Standard Drug Co., 202 Fed. 172 (6th Cir. 1913); Bernard v. Frank, 179 Fed. 516 (2d Cir. 1910).

55. E.g., NLRB v. Rath Packing Co., sutpra note 54. In this case the NLRB secured a court order requiring the Rath Packing Company to disestablish a company union. Supervisory employees of Rath formally disbanded the company union and immediately set up a new union that was the alter ego of the company union. Both the company and its supervisory employees were held in civil contempt. See NLRB v. Hopwood Retinuing Co., 104 F.2d 302 (2d Cir. 1939) ; cf. International Union United Mine Workers v. United States, 177 F.2d 29 (D.C. Cir.), cert. denied, 338 U.S. 871 (1949) (union held guilty of criminal contempt where court felt it was obvious that a positive order by its president would have put an end to disobedience of an injunction even though the president had not formally ordered disobedience).

56. Telling v. Bellows-Claude Neon Co., 77 F.2d 584 (6th Cir. 1935). Contra, United States v. Taystee Baking Co., 55 F. Supp. 490 (N.D. Tex. 1944).

57. See note 39 supra; Commissioners v. Sellew, 99 U.S. 624, 627 (1878).

58. See Land v. Dollar, 190 F.2d 366, 379 (D.C. Cir. 1951), appeal dismissed, 344 U.S. 806 (1952) ; cf. United States v. United Mine Workers, 330 U.S. 258, 306 (1946). However, the disobedience of a subordinate in conformance to a superior's orders may in some situations enable the subordinate to defend a charge of civil contempt by asserting inability to comply. Cf. Maggio v. Zeitz, 333 U.S. 56 (1948); Parker v. United States, 126 F.2d 370, 380 (1st Cir. 1942). And subordinates may also be able to defend criminal contempt because their disobedience is not willful. See note 46 supra. Inability to comply has been held to be a valid defense to a criminal contempt prosecution, Healey v. United States, 186 F.2d 164, 171 (9th Cir. 1950), probably because it indicates the absence of willful disobedience.

59. See note 47 supra. 
Many forms of indirect interference by the school hierarchy will also be actionable as contempt. Persons bound by the decree who undertake evasive action take the risk that the court will impose civil sanctions without informing them in advance that a particular type of behavior violates the decree. ${ }^{60}$ The federal courts repeatedly state that the spirit as well as the letter of their commands must be obeyed, that the substance rather than the form of conduct determines whether or not a contempt has been committed. ${ }^{61}$ Failure of persons bound by the court's orders to take action within their power to prevent others from hindering performance has been held to be actionable as a contempt. ${ }^{62} \mathrm{~A}$ court may even be willing to deem action taken in anticipation of a forthcoming decree a contempt if the action has enabled the parties to nullify the decree. $^{.3}$

60. "[Defendants] undertook to make their own determination of what the decree meant. They knew they acted at their peril....

"It does not lie in [defendants'] . . . mouths to say that they have an immunity from civil contempt because the plan or scheme they adopted was not specifically enjoined. Such a rule would give tremendous impetus to the program of experimentation with disobedience of the law which we condemned in Maggio v. Zeitz.... The instant case is an excellent illustration of how it could operate to prevent accountability for persistent contumacy. Civil contempt is avoided today by showing that the specific plan adopted by respondents was not enjoined. Hence a new decree is entered enjoining that particular plan. Thereafter defendants work out a plan that was not specifically enjoined. Immunity is once more obtained because the new plan was not specifically enjoined. And so a whole series of wrongs is perpetrated and a decree of enforcement goes for naught." McComb v. Jacksonville Paper Co., 336 U.S. 187, 192-93 (1949).

See also NLRB v. Rath Packing Co., 130 F.2d 540 (8th Cir. 1942) ; Philipe v. Window Glass Cutters League, 99 F. Supp. 369 (W.D. Ark. 1951); Economist Furnace Co. v. Wrought Iron Range Co., 86 Fed. 1010 (C.C.D. Ind. 1898).

61. See cases cited note 60 supra; Bigelow v. RKO Radio Pictures, Inc., 170 F.2d 783, 786 (7th Cir. 1948); John B. Stetson Co. v. Stephen L. Stetson Co., 128 F.2d 981, 983 (2d Cir. 1942); In re Rice, 181 Fed. 217, 221 (C.C.M.D. Ala. 1910); Bernard v. Frank, 179 Fed. 516 (2d Cir. 1910); Bate Refrigerating Co. v. Gillett, 30 Fed. 683 (C.C.D.N.J. 18S7) ; cf. Walling v. James V. Reuter, Inc., 321 U.S. 671,674 (1944).

62. United States v. Shipp, 203 U.S. 563 (1906). After a state court had convicted a Negro for rape of a white woman, the Supreme Court ordered Sheriff Shipp to retain the prisoner in his custody to allow the prisoner to prosecute an appeal before the Supreme Court. On allegations that although the sheriff expected a lynching mob, he left the jail inadequately guarded with the result that a mob was able to break into the jail and hang the prisoner, the Supreme Court held that the allegations were sufficient to charge a contempt of the Supreme Court.

63. In Parker v. United States, 126 F.2d 370, 379 (1st Cir. 1942), a regulation under the Agricultural Adjustment Act required a corporation controlled by defendant to make certain payments to the market administrator. Shortly after the regulation became effcctive, defendant entered into a "studied course of conduct over a long period of time" by which he rendered the corporation financially incapable of complying with decrees which where ultimately obtained under the regulation. The First Circuit held that defendant was in civil contempt of the decrees and that an appropriate sanction for his contempt was a compensatory fine payable to the administrator, with provision for commitment of defendant until he paid the fine. Cf. NLRB v. Deena Artware, Inc., 207 F.2d 798, 802 (6th Cir. 1953). But sec United States v. Bryan, 339 U.S. 323, 341 (1950) : "There is, in our jurisprudence, no doctrive of anticipatory contempt." 
It will not be difficult for the courts to use these principles to combat segregation within a nominally interracial school, publicly subsidized "private" schools, or a school district using the so-called individual assignment circumvention device. ${ }^{64}$ The last practice is already authorized by legislation in Alabama, Florida, Georgia, Louisiana and North Carolina. ${ }^{65}$ The statutes authorize school officials to place students in schools for which they are best fitted, and it is expected that the administrators will use vague criteria such as fitness to maintain a bi-racial school system. Officials who systematically segregate Negro students by these three devices can be prosecuted for civil contempt whether or not the practice is authorized by state law. Such activity constitutes violation of the spirit of a desegregation decree. Once such disobedience is shown, plaintiff's right to remedial relief is not impaired by the disobeying party's good faith or lack of intent to defy the court. ${ }^{86}$ However, the courts will probably declare legislative circumvention programs to be a denial of equal protection of the laws before they are willing to hold school officials in contempt for merely complying with the mandates of the legislature. This determination may be made in a suit for a declaratory judgment plus injunctive relief. ${ }^{67}$ The parties administering these programs would then have unequivocal notice that continuation of their behavior would constitute a contempt. But where school boards and officials are discriminating independently of the legislature, the courts may be less likely to warn them of the contemptuous character of their conduct before imposing contempt sanctions. Experimentation in disobedience is not to be encouraged. ${ }^{68}$

64. See text at note 29 supra.

65. N.Y. Times, June 1, 1955, p. 26, cols. 5, 7; Southern School News, Feb. 1956, p. 2.

66. See note 45 supra; of. United States v. Murray, 61 F. Supp. 415 (E.D. Mo. 1945) (city officials held in contempt for threatening to arrest OPA officials if they inspected food lockers under court orders without first obtaining health certificates required by city ordinance).

The imposition of civil contempt sanctions in the form of a conditional fine or commitment would not be harsh even when the officials are acting only in pursuance of state law. These sanctions will be inoperative if the officials immediately obey.

67. 28 U.S.C. $\$ \$ 2201-02$ (1952) allows a person to bring suit for a declaratory judgment as soon as an "actual controversy" exists. Since Brozen has given Negro students an immediate right to start the process of gradual court enforcement of desegregation, see text at notes 9-18 supra, an actual controversy would exist as soon as statutes are enacted or practices are instituted which tend to defeat that right. If the evasion devicu is embodied in a state statute, a suit in the federal courts to enjoin its operation may be brought only in a three-judge district court. 28 U.S.C. $\$ 2281$ (1952). The three-judge court, however, often may not restrain the enforcement of a newly enacted, allegedly unconstitutional statute until the plaintiff is given a reasonable time to obtain a construction of the statute by the state court. 28 U.S.C. $\$ 2284$ (1952), Shipman v. Du Pre, 339 U.S. 321 (1950). Section 2284 does not by its terms require such a stay, and it may not be required where immediate, serious injury is threatened, and where the court feels that no uncertain questions of interpretation are presented. Toomer v. Witsell, 334 U.S. 385, 392 (1948).

See Leflar \& Davis, Segregation in the Public Schools-1953, 67 HARv. L. REV. 377, 424-25 (1954).

68. See McComb v. Jacksonville Paper Co., 336 U.S. 187, 192 (1949). 
Economic coercion may be difficult to reach by contempt proceedings. ${ }^{69}$ Economic resistance by named parties has been deemed a civil contempt, but this type of interference is usually undertaken by individuals not bound by the decree and thus not amenable to civil contempt. ${ }^{70}$ However, if the persons exerting economic coercion act in concert with the school hierarchy under a plan of organized interference, these persons might also be subject to suit in civil contempt. ${ }^{71}$ It may even be difficult to use criminal contempt to combat economic resistance undertaken by persons not bound. The courts have seldom punished such persons for nonviolent conduct which frustrates compliance with a decree. But if violent coercion and picketing can subject nonparties to a criminal contempt prosecution, ${ }^{22}$ there is no theoretical reason for treating the more subtle techniques differently. Even if a prosecution for criminal contempt were possible, however, it would be especially difficult to establish the willfulness required by that proceeding.

Even initial judicial resistance may possibly be reached by civil contempt proceedings. A superior tribunal has the power to imprison judges on inferior tribunals until they obey its commands, although such power is rarely exercised. ${ }^{73}$ If district judges refuse to require defendants to make a prompt and reasonable start, plaintiffs may apply to the appellate court for a mandamus. If the judge still refuses, plaintiffs should be able to sue the district judge in the appellate court for civil contempt. ${ }^{74}$ If plaintiffs can demonstrate the judge's disobedience by clear and convincing evidence, the appellate court does not have

69. For discussion of the nature of the economic resistance to be expected, see note 28 supra and accompanying text; U.S. News \& World Report, May 28, 1954, pp. 21-24.

70. See note 39 supra and accompanying text.

71. See Fed. R. CIv. P. 65(d) ; text at note 39 supra. See also L. E. Waterman Co. v. Standard Drug Co., 202 Fed. 167, 172 (6th Cir. 1913) (person not otherwise bound by injunction cited for contempt in that he "aided and assisted" the company in disobeying the injunction).

72. E.g., United States v. Debs, 64 Fed. 724, 762-66 (C.C.N.D. Ill. 1894), aff'd sub nom. In re Debs, 158 U.S. 564 (1895) ; McCourtney v. United States, 291 Fed. 497 (8th Cir. 1923) ; Mackall v. Ratchford, 82 Fed. 41 (C.C.D.W. Va. 1897); See Moskovitz, Contempt of Injunctions Civil and Criminal, 43 CoLux. L. Rev. 780, 799 (1943).

73. Cf. In re Nevett, 117 Fed. 448 (8th Cir. 1902). In this case the Eighth Circuit held that a United States district court did not err in committing judges of the County Court of St. Clair, Missouri for contempt of a mandamus issued by the district court. However, it is not clear from the report whether the county court was a court of general jurisdiction. See also In re Copenhaver, 54 Fed. 660 (C.C.WJD. Mo. 1893). Superior state tribunals have held lower court judges in contempt for failure to comply with a mandamus. People ex rel. Bristol v. Pearson, 4 Ill. 270 (1841) ; cf. Ex parte Carnochan, $1 \mathrm{Ga}$. Rep. Ann. 109 (Super. Ct., Chatham Cty. 1810). And no reason appears for denying the same remedy if a federal court issues a mandamus to a lower federal court. See 18 U.S.C. \& 401 (3) (1952).

74. Mandamus may be unnecessary if it is clear that the district court is disobedient, because a Brozm-type order is directed to the district court. See notes 7-8 supra and accompanying text. Disobedience by the court would then come within 18 U.S.C. § 401(3) (1952): "A court of the United States shall have the power to punish by fine and imprisonment such contempt of its authority and none other, as - ... (3) disobedience to its lawful writ, process, order, rule, decree, or command." 
unlimited discretion to deny remedial relief. ${ }^{75}$ And a district judge who disobeys a Supreme Court order addressed to him becomes subject to the virtually unlimited contempt powers of that Court. ${ }^{70}$ After a start towards integration has been made, it will be extraordinarily difficult to contend successfully that district court grants of additional time were made in disobedience of the appellate decree, so that time extensions will lie almost wholly within the discretion of the district court. ${ }^{77}$ But if the lapse of a long period produces no advance towards desegregation, Negro plaintiffs may be able to show that the factors which the appellate order permitted the lower court to consider could never have justified the long delay. ${ }^{78}$ While it is most unlikely that contempt sanctions will be applied against district court judges, the possibility illustrates the broad reach of the contempt power. ${ }^{79}$

The rule that a decree must give specific commands before contempt proceedings may be brought for its violation is not apt to curb the efficacy of the contempt power in combatting direct or indirect interference. ${ }^{80}$ The appellate courts may justifiably consider some district court decrees too vague to give parties or nonparties a precise idea of their obligations. But parties and nonparties have often been deemed in contempt for violation of decrees of consider-

75. See note 53 supra and accompanying text.

76. It is still an unsettled question whether Congress can limit the contempt power of the Supreme Court by legislation, since, unlike the lower federal courts, the Supreme Court is a creature not of statute but of the Constitution. See Ex parte Robinson, 86 U.S. (19 Wall.) 505,510 (1873). An illustration of the broad nature of the contempt power of the Supreme Court is found in United States v. Shipp, 203 U.S. 563, 575 (1906).

77. Brown v. Board of Education, 349 U.S. 294 (1955) ; see text at note 17 supra.

78. " $[\mathrm{T}]$ he power of a trial court to act in any litigation after the issuance of a mandate on appeal is limited by an obligation to do nothing contrary to either the letter or spirit of the mandate, as explained or elucidated in the opinion." Goldwyn Pictures Corp. v. Howells Sales Co., 287 Fed. 100, 102 (2d Cir. 1923). Cf. Ex parte Morris, 76 U.S. (9 Wall.) 605,607 (1869).

79. The ability of the appellate court to enter the order that it feels the lower court should have entered may provide an easier way of circumventing recalcitrant district court judges. 28 U.S.C. $\$ 2106$ (1952), Troyak v. Enos, 204 F.2d 536 (7th Cir. 1953). If the appellate court can enter such an order, any violation would be a contempt punishable directly by the appellate court. But it has been held that the appellate court may not dictate the judgment where it cannot finally dispose of the case. Warsaw-Wilkinson $\mathrm{Co}$. v. Exchange Mut. Life Ins. Co., 192 Fed. 666 (C.C.E.D. Pa. 1910). Arpellate court order: would rarely be able to dispose finally of a desegregation case, especially since Brotat stated that the problem of implementation was one primarily within the cognizarce of the district courts. Brown v. Board of Education, 349 U.S. 294, 299 (1955).

80. "Certainly before one may be punished for contempt for violating a court order, the terms of such order should be clear and specific, and leave no doubt or uncertainty in the minds of those to whom it is addressed." McFarland v. United States, 295 Fed. 648, 650 (7th Cir. 1923).

See also Terminal R.R. Ass'n v. United States, 266 U.S. 17, 29 (1924), and NLRE v. Norfolk Shipbuilding \& Drydock Corp., 195 F.2d 632 (4th Cir. 1952), illustrating the difficulty of obtaining a contempt conviction when the decree is vaguely wordcd. Cf. J. I. Case Co. v. NLRB, 321 U.S. 332, 341 (1944). See Note, 54 Coluvr. L. Rev. 603 (1954). 
able generality. ${ }^{81}$ And there is imposing authority for the proposition that the decree should be broad enough to prevent evasion. ${ }^{82}$ Where a proclivity for resistance has been shown, broad general commands are permissible so as not to facilitate experimentation with evasionary devices. ${ }^{83}$ In addition, failure to move for a dissolution or modification of a court order before engaging in possibly contemptuous conduct has been held to estop parties from defending a contempt prosecution on the ground that the order was vague or ambiguous. ${ }^{84}$

When Negro plaintiffs have a choice between civil and criminal contempt, they will find it advantageous.to invoke civil contempt rather than ask the court to initiate criminal proceedings. Although the courts can institute criminal contempt whenever they deem resistance by bound parties to be flagrant or violent, this is rarely done unless plaintiff complains to the court that the resistance is of such a serious nature as to require a punitive sanction. ${ }^{85}$ On the other hand plaintiffs can always institute civil contempt on their own behalf. ${ }^{86}$ The civil proceeding will not require either a jury trial, ${ }^{87}$ proof beyond a reasonable doubt, or proof of willful disobedience. ${ }^{88}$ For criminal contempt a jury trial

81. Excerpts from the injunction in the famous $D c b s$ case are illustrative of a broadly worded injunction that has both specific and "catch all" provisions: "[D]efendants and all persons combining and conspiring with them and all persons whosoever, were commanded and enjoined to desist and refrain-

(1) From in any way or manner interfering with, obstructing or stopping any of the business of any of the following named railroads.... (2) From in any way interfering with. ... [various] trains ... (4) From in any manner interfering with, injuring or destroying the property of any of said railroads ... (10) From doing any act whatever in furtherance of any conspiracy or combination to restrain . . . said railroad companies or receivers in the free and unhindered control and handling of interstate commerce over the lines of such railroads ... (11) From ordering, directing, aiding, assisting, or abetting, in any manner whatever any person or persons to commit any or either of the acts aforesaid,'" United States v. Debs, 64 Fed. 724, 726-27 (C.C.N.D. I1l. 1894), aff'd sub nom. In re Debs, 158 U.S. 564 (1895). (Emphasis added.) See Cassidy v. Puett Elec. Starting Gate Corp., 182 F.2d 604, 605 (4th Cir. 1950). Here defendants and their associates were enjoined from "directly or indirectly and ... from in any way infringing any claim of said Patent ... under pains and penalties that may fall thereon. Hereof fail not at your peril."

82. "[T] he United States is entitled to effective relief. To that end the decree should enjoin acts of the sort that are shown by the evidence to have been done or threatened in furtherance of the conspiracy. It should be broad enough to prevent evasion." (Emphasis added.) Local 167, International Brotherhood of Teamsters v. United States, 291 U.S. 293, 299 (1934). See McComb v. Jacksonville Paper Co., 336 U.S. 187, 192-93 (1949); May Stores Co. v. NLRB, 326 U.S. 376, 391 (1945).

83. See, e.g., McComb v. Jacksonville Paper Co., supra note 82, at 192.

84. McComb v. Jacksonville Paper Co., 336 U.S. 187 (1949); Economist Furnace Co. v. Wrought Iron Range Co., 86 Fed. 1010, 1011 (C.C.D. Ind. 1898) (dictum).

85. Sce, e.g., United States v. United Mine Workers, 330 U.S. 258, 267 (1947) ; Kreplik v. Couch Patents Co., 109 Fed. 565 (1st Cir. 1911).

86. Wright, et al., Civil and Criminal Contempt in the Federal Courts, 17 F.R.D. 167, 172 (1955), and cases there cited. See Kreplik v. Couch Patents Co., supra note 85 (plaintiff institutes mixed contempt proceeding).

87. Sie note 41 supra.

:S. Sec notes 44-45 supra. 
will often be necessary because the resistance may also violate a state or federal statute. ${ }^{80}$ Violence will often violate state statutes, and any resistance may constitute a federal offense under the Civil Rights Acts. ${ }^{90}$ Both Southern district judges and Southern juries may be unsympathetic to integration at present, but the judges' life tenure enables them to be relatively independent of local opinion, and their respect for higher judicial authority may well override any personal dislike of the task they have been commanded to perform. ${ }^{01}$

\section{The Civil Rights Acts}

Although resistance may be most effectively neutralized through use of the contempt power, the Civil Rights Acts afford alternative and supplementary enforcement weapons.92 Brown and Bowling hold school segregation to be a denial of equal protection in the states and of Fifth Amendment due process in the District of Columbia. ${ }^{93}$ These rights are protected by several surviving provisions of the Civil Rights Acts. Sections 241 and 242 of the Criminal Code and sections 1983 and 1985(3) of title 42 are the provisions which can be used to combat much of the expected resistance. ${ }^{94}$ Unlike the federal contempt power, use of the CRA depends only on the existence of a protected right and not on the existence of a decree which has been violated.95

Under section 242 of the Criminal Code anyone acting under color of law who willfully deprives another of the equal protection of the laws may be indicted for a misdemeanor, punishable by a $\$ 1,000$ fine or a one-year prison

89. See note 43 supra.

90. See text at notes $96-110$ infra.

91. Unlike state executive officials, federal district court judges have neither stated nor intimated that they will not enforce the commands of the Supreme Court. Indeed, recent decisions of the federal courts indicate that the district courts are seriously attempting to comply with the Brozen mandates. E.g., Hoxie School District No. 46 v. Brewer, 135 F. Supp. 296 (E.D. Ark. 1955), temporary injunction made permanent, 24 U.S.L. WEEK 2323 (E.D. Ark. Jan. 9, 1956) (discussed at note 27 supra) ; McSwain v. County Board of Education, 24 U.S.L. WEEK 2323 (E.D. Tenn. Jan. 4, 1956) (federal district court in Tennessee orders Anderson County to complete desegregation before the beginning of the 1956 Fall term) ; Willis v. Walker, 136 F. Supp. 177 (W.D. Ky. 1955) (discussed at note 22 supra) ; Frasier v. Board of Trustees, 134 F. Supp. 589 (M.D.N.C. 1955), aff'd, 24 U.S.L. WeEK 3232 (U.S. March 5, 1956) (three-judge district court in North Carolina rejected contention that Brown is applicable only to public elementary and high schools and held that the University of North Carolina cannot refuse to process applications for admission solely because the applicants are Negroes). Nineteen rulings involving school segregation that have been promulgated since the date of the Brown decree are briefly summarized in Southern School News, Feb. 1956, p. 1, col. 1.

92. See, generally, Gressman, The Unhappy History of Civil Rights Legislation, 50 Mice. L. Rev. 1323 (1952); Poole, Statutory Remedies for the Protection of Civil Rights, 32 Ore. L. Rev. 210 (1953) ; Putzel, Federal Civil Rights Enforcement: A Current Appraisal, 99 U. PA. L. Rev. 439 (1951).

93. See text at notes 4-5 supra.

94. See notes $96,106,111,121$ infra.

95. See note 34 supra. For a discussion of the desegregation rights which are protected, see text at notes 9-18 supra. 
term or both. ${ }^{86}$ And if private parties act in concert with state officials who are committing a section 242 offense, both may be prosecuted for a conspiracy to violate the statute. ${ }^{97}$ This surviving section of the original Civil Rights Acts has been used primarily to punish deprivations of the right to due process and equal protection in a law enforcement context where violence was present, but there exists no legal impediment to its use to punish a denial of equal protection in a state school system.99 The Supreme Court has affirmatively declared that section 242 was enacted to enforce the rights protected by the Fourteenth Amendment, particularly to combat discrimination against Negroes. ${ }^{100}$ Since Brown has made it clear that school segregation violates the Fourteenth Amendment, section 242 can be used against state school officials

96. "Whoever under color of any law, statute, ordinance, regulation, or custom, willfully subjects any inhabitant of any State, Territory, or District to the deprivation of any rights, privileges, or immunities secured or protected by the Constitution or laws of the United States, or to different punishments, pains, or penalties, on account of such inhabitant being an alien, or by reason of his color, or race, than are prescribed for the punishment of citizens, shall be fined not more than $\$ 1,000$ or imprisoned not more than one year or both." 1S U.S.C. \$ 242 (1952), formerly 18 U.S.C. $\$ 52$ (1926).

97. "If two or more persons conspire ... to commit any offense against the United States ... and one or more of such persons do any act to effect the object of the conspiracy, each shall be fined not more than $\$ 10,000$ or imprisoned not more than five years or both.

"If, however, the offense the commission of which is the object of the conspiracy, is a misdemeanor only, the punishment for such conspiracy shall not exceed the maximum punishment provided for such misdemeanor." 18 U.S.C. $\$ 371$ (1952). This statute was applied to reach private parties for a conspiracy to violate $\$ 242$ in Brown v. United States, 204 F.2d 247, 249 (6th Cir. 1953) ; Koehler v. United States, 189 F.2d 711 (5th Cir. 1951) ; Culp v. United States, 131 F.2d 93, 98-99 (8th Cir. 1942).

98. E.g., Williams v. United States, 341 U.S. 97 (1951) (conviction of a detective who mistreated prisoner) ; United States v. Jones, 207 F.2d 785 (5th Cir. 1953) (same) ; Koehler v. United States, 189 F.2d 711 (5th Cir. 1951) (conviction of law officer who mistreated prisoner); Lynch v. United States, 189 F.2d 476 (5th Cir. 1951) (conviction of police officers who yielded Negro prisoners to non-officer Klansmen who subjected them to physical brutality).

99. In United States v. Buntin, 10 Fed. 730 (C.C.S.D. Ohio 1882), a teacher of the only public school in a subdistrict in Clermont County, Ohio, refused to allow certain Negro children to attend the school. The teacher was indicted under the statutory predecessor to $\S 242$ and the circuit judge's charge to the jury included the following: "If, therefore, this defendant did exclude the colored boy named in the indictment from the privileges of the school taught by him, after being requested by the trustees of the subdistrict to permit him to enter it, claiming the right to do so under authority of the statute providing for the separate education of colored children in schools to be established and maintained for that purpose, and did so on account of his color, the court instructs you that you ought to find him guilty as charged unless you shall find in his favor the question of fact to which I will hereafter direct your attention. ... [ [But if you shall find] there was such a school in the district... affording substantially the same educational advantages as were afforded by the school from which the prosecuting witness was excluded, it was his duty to have come there, and the defendant did him no wrong in the exclusion complained of." Id. at 732, 735.

100. "Sec. 20 [ $\$ 242]$ was enacted to enforce the Fourteenth Amendment." Screws v. United States, 325 U.S. 91, 98 (1945). See also Irvine v. California, 347 U.S. 128, 137 (1954) (concurring opinion per Clark, J.). 
who continue to enforce segregation in opposition to the commands of a district court. Section 242 liability ensues whether or not the action is authorized by state law, ${ }^{101}$ and even if the official is merely enforcing the commands of a superior officer. ${ }^{102}$

Deliberate official inaction, particularly the failure of state law enforcement officials to take feasible action to protect those asserting their constitutional rights from mob violence, has been held to subject such officers to the penalties of section 242.103 Although it is only within the law enforcement context that inaction has prompted a section 242 prosecution, failure of school officials to use all their available powers to implement desegregation as ordered may also constitute a denial of equal protection, punishable under 242. If law enforcement officials can be indicted for failing to use their available powers to prevent a mob from attacking Negro children on the way to an integrated school, school board members and school officials who fail to use all their powers to afford these children an integrated school should be in no better position. A full development of the incipient doctrine that inaction may constitute a denial of equal protection under section 242 would result in application of the statute not only to direct failure in complying with a district court order, but also to the failure of school officials to attempt to discipline striking white students, and to the acquiescence by school board members in discriminatory practices by lower school officials.

A limitation on the effectiveness of section 242 may result from the requirement that the defendant be shown to have been motivated by a specific intent to deprive his victim of a constitutional right. ${ }^{104}$ The requirement is apt to prove troublesome in cases of nonsystematic discrimination against selected Negroes, or of failure by law enforcement officials to protect Negro school children from mob violence, for in these cases defendants can argue that their

101. E.g., Screws v. United States, supra note 100, at 107-08; Williams v. United States, 179 F.2d 656, 660 (5th Cir. 1950), aff'd, 341 U.S. 97 (1951).

102. See United States v. Konovsky, 202 F.2d 721, 730 (7th Cir. 1953). Although it reversed a $\$ 242$ conviction for procedural errors, the Seventh Circuit saw no error in the district court's refusal to instruct the jury to acquit officers who failed to protect Negroes from mob violence merely because the officers were acting pursuant to orders from their superior officers.

103. E.g., Lynch v. United States, 189 F.2d 476, 481 (5th Cir. 1951) (abstracted at note 98 supra) ; Catlette v. United States, 132 F.2d 902, 907 (4th Cir. 1943). In this case a deputy sheriff allowed a town mob to abuse and restrain Jehovah's Witnesses who sought his protection before they attempted to proselytize in the town. On appeal a judgment against Catlette imposing a $\$ 1,000$ fine and a twelve-month prison term was sustained on the alternative ground that Catlette's inaction constituted a denial of equal protection actionable under $\$ 242$. Cf. United States v. Konovsky, supra note 102, at 729; United States v. Blackburn, 24 Fed. Cas. No. 14, at 1158 (W.D. Mo. 1874).

104. Screws v. United States, 325 U.S. 91 (1945). Recent cases applying the requirement of Screws indicate that the appellate court will not reverse a conviction as long as the judge's charge includes a statement to the effect that defendants must have intended to deprive their victim of a specific constitutional right. E.g., Clark v. United States, 193 F.2d 294 (5th Cir. 1951) ; Koehler v. United States, 189 F.2d 711 (5th Cir. 1951) ; Williams v. United States, 179 F.2d 656 (5th Cir. 1950), aff'd, 341 U.S. 97 (1951). 
conduct was prompted by other motives. Officials who systematically and deliberately segregate all Negro children will find it more difficult to prove they had no purpose to deprive Negroes of their constitutional rights; for it may be argued that the required intent is implicit in the systematic segregation of the races. ${ }^{105}$

Under section 241 of the Criminal Code any persons who conspire to deprive a citizen of certain constitutional rights face maximum punishments of a $\$ 5,000$ fine or ten years in prison or both. ${ }^{106}$ The statute has been construed to protect only those rights arising from the relation of the citizen to the federal government, and not the rights protected by the Fourteenth Amendment against state infringement. ${ }^{107}$ Section 241 has been held to protect the right of a citizen to institute contempt proceedings for violation of a federal court order, ${ }^{108}$ and it should also protect his right to institute proceedings in the federal courts for the purpose of asserting federally recognized rights. ${ }^{109}$ Thus, section 241 would be applicable against any conspiracy designed to intimidate Negroes from in-

105. See Note, 40 GEo. L.J. 566 (1952).

106. "If two or more persons conspire to injure, oppress, threaten or intimidate any citizen in the free exercise or enjoyment of any right or privilege secured to him by the Constitution or laws of the United States, or because of his having exercised the same; or

"If two or more persons go in disguise on the highway, ... with intent to prevent or hinder his free exercise or enjoyment of any right or privilege so secured-

They shall be fined not more than $\$ 5,000$ nor imprisoned not more than ten years or both." 18 U.S.C. \$ 241 (1952), formerly 18 U.S.C. \$ 51 (1926).

107. United States v. Williams, 341 U.S. 70 (1951). This proposition was enunciated by Justice Frankfurter in the opinion of the Court, but on this issue the justices were even$1 y$ divided. Justices Douglas, Burton, Reed and Clark felt that $\$ 241$ also embraced a conspiracy to deprive a citizen of the rights protected by $\$ 242$. Black concurred with Frankfurter, Jackson, Minton and Vinson for an independent reason. If the question is ever reconsidered by the Court, the position of the dissenters may prevail, for all four dissenters are still on the Court, while only two justices remain who concurred in the opinion of the Court. See discussion of $\$ 241$ in Eurerson \& Haber, Political and Civil Rigets 70 (1952).

In the recent case of Hoxie School District No. 46 v. Brewer, 24 U.S.L. WEEK 2323 (E.D. Ark. Jan. 9, 1956), the court in a dictum implied that interference by private persons with the rights of Negro pupils granted by the Fourteenth Amendment is actionable under $\S 241$.

108. United States v. Lancaster, 44 Fed. 885 (C.C.W.D. Ga. 1890).

109. In Motes v. United States, 178 U.S. 458 (1900), $\$ 241$ was used to punish conspirators who intimidated a private citizen in the exercise of his right to notify a United States marshall of a violation of the internal revenue laws. Accord, In re Quarles, 158 U.S. 532 (1895). A citizen who attempts to notify a court of a violation of the Fourteenth Amendment and who attempts to make use of the court machinery provided for protection of those rights should be similarly protected. See also Foss v. United States, 266 Fed. 881 (9th Cir. 1920) ( $\$ 241$ used to punish persons who conspired to intimidate a citizen from exercising his right to appear as a witness in a land contest held pursuant to federal law).

Section 241 should also be of use in punishing interference, by federal officials and private persons within the District of Columbia, of the Negro child's right to attend integrated schools. This right, being guaranteed against infringement by the federal government, can certainly be said to arise from the relation of the individual to the federal government. Although the rights which the courts have thus far protected under $\$ 241$ have not arisen 
stituting Brown-type suits or from invoking the contempt powers of the federal courts in order to combat resistance to their decrees. It should also be applicable against members of an economic conspiracy fashioned in order to intimidate Negroes into failing to assert their new rights by court action. Members of the citizens councils already formed in Mississippi and elsewhere to withdraw credit from Negro leaders, and otherwise to discourage by economic intimidation the implementation of desegregation, could be indicted under this section. ${ }^{110}$

Under section 1983 of title 42, Negro school children who are deprived of their desegregation rights by persons acting under color of state law can sue for damages or can obtain injunctive relief against such action. ${ }^{111}$ If private persons conspire with officials who are acting under color of state law, they too are liable under section $1983 .{ }^{112}$ Although there is authority for the proposition that the rights protected by section 1983 are only those secured by the due process clause of the Fourteenth Amendment and not the equal protection clause, ${ }^{113}$ the majority of the cases have assumed that section 1983 embraces

from the prohibitions on federal action embodied in the first ten amendments, no exclusion of the latter class of rights from the coverage of the statute can be implied from the controlling decision of United States v. Williams, 341 U.S. 70 (1951).

110. See Southern School News, Nov. 1955, p. 1. col. 4 (Oklahoma reports the first organization of a Citizens Council, a movement spreading out of Mississippi into Alabama, Louisiana, Florida, South Carolina, Texas, and other states) ; U.S. News \& World Report, May 28, 1954, pp. 21-24.

111. "Every person who, under color of any statute, ordinance, regulation, custom, or usage, of any State or Territory, subjects or causes to be subjected, any citizen of the United States or other person within the jurisdiction thereof to the deprivation of any rights, privileges, or immunities secured by the Constitution and laws, shall be liable to the party injured in an action at law, suit in equity, or other proper proceeding for redress." 17 STAT. 13 (1871), 42 U.S.C. $\$ 1983$ (1952), formerly 8 U.S.C. $\$ 43$ (1946).

Damages have been awarded to plaintiffs for deprivations of constitutional rights, c.g., Myers v. Anderson, 238 U.S. 368 (1915) ; Solomon v. Pennsylvania R.R., 96 F. Supp. 709 (S.D.N.Y. 1951) ; cf. Hobson v. York Studios, Inc., 145 N.Y.S.2d 162 (N.Y. Munic. Ct. 1955), and numerous decisions, in remanding cases for trial, have specifically sustained plaintiff' right to damages, e.g., Lane v. Wilson, 307 U.S. 268 (1939) ; Nixon v. Herndon, 273 U.S. 536 (1927) ; Flemming v. South Carolina Elec. \& Gas Co., 224 F.2d 752 (4th Cir. 1955) ; McDonald v. Key, 224 F.2d 608 (10th Cir. 1955). See also Nash v. Air Terminal Services, Inc., 85 F. Supp. 545, 549 (E.D. Va. 1949) (plaintiff entitled to "such damages as may have been occasioned her ... and she need not, as contended by the defendants, prove direct physical injury in order to recover damages").

112. 'The 'individuals' are said to have conspired with the 'officials.' When, because of the participation of 'officials, action is taken which may be characterized as effecting a deprivation, 'under color of law, of rights secured by the Constitution, the 'individuals' also fall within the strictures of [\$ 1983]." Robeson v. Fanelli, 94 F. Supp. 62, 70 (S.D. N.Y. 1950). See also Watkins v. Oaklawn Jockey Club, 86 F. Supp. 1006, 1016-17 (W.D. Ark. 1949), aff'd, 183 F.2d 440 (8th Cir. 1950); Condra v. Leslie \& Clay Coal Co., 101 F. Supp. 774, 777 (E.D. Ky. 1952).

113. Ortega v. Ragen, 216 F.2d 561, 563 (7th Cir. 1954) (alternative holding); Jennings v. Nester, 217 F.2d 153, 154 (7th Cir. 1954) (dictum) ; McShane v. Moldovan, 172 F.2d 1016, 1018 n.2 (6th Cir. 1949) (dictum) ; Bottone v. Lindsley, 170 F.2d 705, 706 (10th Cir. 1948) (dictum). 
both sets of rights. ${ }^{114}$ The former proposition was first stated in a dictum by the Tenth Circuit, ${ }^{115}$ a dictum for which the court had no valid authority, either from the previous cases, legislative history or the wording of the Civil Rights Acts themselves. ${ }^{110}$ Courts which have followed this dictum seem to have been influenced by the fact that a companion statute, section 1985 (3), refers in explicit terms to the right to equal protection, ${ }^{117}$ whereas section 1983 refers only to the "rights secured by the Constitution." 118 From this they infer that each section was designed to protect a separate right. But if this were so, section 1985(3) probably would not have been confined to a conspiracy and would not have provided only for a remedy in damages while section 1983 afforded a remedy against individuals both in law and equity. ${ }^{119}$ Furthermore, suits by Negroes to compel equalization of school and recreational facilities, grounded on a denial of equal protection, have often been brought under section 1983, and the statutory relief has been given as a matter of course when plaintiffs have been able to prove substantial inequality. ${ }^{120}$

Whether section 1985(3) itself can be used to remedy deprivations of desegregation rights is doubtful. This statute authorizes suits against all persons who conspire for the purpose of depriving anyone of the equal protection of the laws; the plaintiff may recover damages if any of the conspirators have

114. "The equal protection of the laws is guaranteed by the Fourteenth Amendment ... and by 42 U.S.C.A. $\S 1981$, and liability for deprivation of such right is provided by 42 U.S.C.A. § 1983." Flemming v. South Carolina Elec. \& Gas Co., 224 F.2d 752, 753 (4th Cir. 1955) (Negro woman required to change her seat in accord with South Carolina segregation law held to have the right to sue the bus company for damages under $\S 1983$ ); McDonald v. Key, 224 F.2d 608, 609 (10th Cir. 1955) (damage action for denial of equal protection under $\$ 1983$ ) ; Valle v. Stengel, 176 F.2d 697, 704 (3d Cir. 1949); Westminster School Dist. v. Mendez, 161 F.2d 774 (9th Cir. 1947); Williams v. Kansas City, 104 F. Supp. 848 (W.D. Mo. 1952) ; Solomon v. Pennsylvania R.R., 96 F. Supp. 709 (S.D.N.Y. 1951).

"[Section 1983] includes the Fourteenth Amendment and such privileges and immunities as are secured by the due process and equal protection clauses, as well as by the privileges and immunities clause of that Amendment." Hague v. CIO, 307 U.S. 496, 526 (1939) (concurring opinion per Stone, J.).

115. Bottone v. Lindsley, 170 F.2d 705, 706 (10th Cir. 1948).

116. See Poole, Statutory Remedics for the Protection of Cizil Rights, 32 ORE. L. REv. 210, 218-20 (1953).

117. See note 121 infra.

118. See note 111 supra.

119. Ibid.

120. E.g., Westminster School Dist. v. Mendez, 161 F.2d 774 (9th Cir. 1947) ; Holmes v. City of Atlanta, 124 F. Supp. 290 (N.D. Ga. 1954), aff'd, 223 F.2d 93 (5th Cir. 1955); Draper v. St. Louis, 92 F. Supp. 546 (E.D. Mo.), appeal dismissed, 186 F.2d 307 (Sth Cir. 1950) ; Pitts v. Board of Trustees, 84 F. Supp. 975 (E.D. Ark. 1949) ; cf. Rice v. Elmore, 165 F.2d 387 (4th Cir. 1947), cert. denied, 333 U.S. 875 (1948); Providence Journal Co. v. McCoy, 94 F. Supp. 186, 194-95 (D.R.I. 1950), aff'd, 190 F.2d 760 (1st Cir.), ccrt. denied, 342 U.S. 894 (1951). And complaints brought under $\$ 1983$, alleging a denial of equal protection, have been held to state causes of action. E.g., Bruce v. Stilwell, 206 F.2d 554 (5th Cir. 1953) ; Valle v. Stengel, 176 F.2d 697 (3d Cir. 1949) ; Kerr v. Enoch Pratt Free Library, 149 F.2d 212 (4th Cir. 1945). 
injured him or his property, or have deprived him of his rights as a United States citizen. ${ }^{121}$ Presumably the "rights" referred to are not Fourteenth Amendment rights but only those "national" rights which section 241 protects. ${ }^{122}$ Therefore, section 1985 (3) will usually aid a Negro child to protect his desegregation rights only if personal injury or property damage is involved. ${ }^{123}$

Unlike section 1983, this statute is not by its terms limited to defendants who act under color of law. But whether it can in fact be used effectively against private persons remains to be seen. There are two formidable obstacles to such a use of the statute. First, the Supreme Court in Collins v. Hardyman ${ }^{124}$ has established a highly restrictive test of what constitutes a denial of equal protection of the laws by private persons. ${ }^{125}$ Under the Collins test, defendants must at least seek to "influence" or "manipulate" the law, and there is a suggestion that they must also prevent plaintiffs from obtaining redress for the alleged wrongs in the state courts. ${ }^{126}$ The Court cited the activities of the post-Civil War Ku Klux Klan as an example of conduct which "may" have amounted to a denial of equal protection by private persons. ${ }^{127}$

Even if modern segregationists do in some areas undertake action which will satisfy the Collins test, constitutional problems pose a second obstacle to the application of section 1985(3). Whether Congress can impose civil liability on private persons for denying others the equal protection of the laws has never

121. "If two or more persons in any State or Territory conspire or go in disguise on the highway or on the premises of another for the purpose of depriving, either directly or indirectly, any person or class of persons of the equal protection of the laws, or of equal privileges and immunities under the laws; or for the purpose of preventing or hindering the constituted authorities of any State or Territory from giving or securing to all persons within such State or Territory the equal protection of the laws . . . in any case of conspiracy set forth in this section, if one or more persons engaged therein do, or cause to be done, any act in furtherance of the object of such conspiracy, whereby another is injured in his person or property, or deprived of having and exercising any right or privilege of a citizen of the United States, the party so injured may have an action for the recovery of damages, occasioned by such injury or deprivation, against one or more of the conspirators." 12 STAт. 284 (1861), 17 STAт. 13 (1871), 42 U.S.C. $\$ 1985$ (3) (1952), formerly 8 U.S.C. $\$ 47(3)(1946)$.

122. See Miles v. Armstrong, 207 F.2d 284 (7th Cir. 1953). See also notes 107-10 supra and accompanying text.

123. The Seventh Circuit has suggested that the statute protects only "national" rights. Miles v. Armstrong, 207 F.2d 284 (7th Cir. 1953). See also Robeson v. Fanelli, 94 F. Supp. 62 (S.D.N.Y. 1950). The Eighth Circuit construes the statute to protect the Fourteenth Amendment right to equal protection, but only against state infringenent. Moffett v. Commerce Trust Co., 187 F.2d 242 (8th Cir. 1951). The statute has also been construed to protect both sets of rights. Arkansas v. Central Surety \& Ins. Corp., 102 F. Supp. 444, 447 (W.D. Ark. 1952).

124. 341 U.S. 651 (1951).

125. For a discussion of what constitutes a denial of equal protection of the laws by state officials, see text at notes 139-46 infra.

126. Collins v. Hardyman, 341 U.S. $651,661-62$ (1951). See also McNutt v. Unitcd Gas, Coke \& Chemical Workers, CIO, 108 F. Supp. 871, 875-76 (W.D. Ark. 1952).

127. Collins v. Hardyman, 341 U.S. 651, 662 (1951). 
lueen decided by the Supreme Court. ${ }^{128}$ A similar statute creating criminal liability was declared unconstitutional, ${ }^{120}$ and the Seventh Circuit has suggested that if section 1985(3) does extend to private action, it too is unconstitutional. ${ }^{130}$ Since the application of the statute to private persons is so doubtful, only those acting under color of law will normally be made defendants in a civil suit under the Civil Rights Acts. ${ }^{131}$ And section 1983 reaches these persons as well as private persons who conspire with them :132 so section 1983 will be the principal civil sanction for Negro children who seek to remedy deprivations of their desegregation rights.

The application of the civil provisions of the CRA involve a number of difficulties not present in the application of civil contempt sanctions. To recover damages under the CRA a jury is necessary, ${ }^{133}$ whereas compensatory fines for violations of federal court decrees may be imposed without the intervention of a jury. ${ }^{134}$ In addition, the courts have promulgated three doctrines which operate to limit the use of sections 1983 and 1985(3).

The first difficulty results from the doctrine requiring the exhaustion of administrative remedies before a party may resort to the federal courts. ${ }^{135}$ At least one Southern state has attempted to take advantage of this rule by providing for an involved, time-consuming system for review of decisions to place students in schools for which they are best fitted. ${ }^{130}$ But exhaustion of administrative remedies has not been required where these remedies do not afford the plaintift review by disinterested parties or where the review system is of such

138. "It is apparent that if this complaint meets the requirements of this Act, it raises constitutional problems of the first magnitude that, in the light of history, are not without difficulty. These would include issues as to congressional power under and apart from the Fourteenth Amendment, the reserved power of the States, the content of rights derived from national as distinguished from state citizenship, and the question of separability of the Act in its application to those two classes of rights .... We think that Congress has not, in the narrow class of conspiracies defined by this statute, included the conspiracy charged here. We therefore reach no constitutional questions." Id. at 659,662 .

129. United States v. Harris, 106 U.S. 629 (1882).

130. Miles v. Armstrong, 207 F.2d 284 (7th Cir. 1953).

131. As under $\$ 241$, private persons can be made defendants when "national" rights are involved. See text at notes 107-10 supra.

132. See text at note 112 supra.

133. E.g., Downie v. Powers, 193 F.2d 760 (10th Cir. 1951).

134. See note 41 supra.

135. E.g., Natural Gas Co. v. Slattery, 302 U.S. 300, 310-11 (1937) ; Davis v. Arn, 199 F.2d 424 (5th Cir. 1952) ; Cook v. Davis, 178 F.2d 595, 601 (5th Cir. 1949) ; Lane v. Wilson, 307 U.S. 268, 274 (1939) (dictum); see Carson v. Board of Education, 227 F.2d 789 (4th Cir. 1955). But state remedies having "the indicia of a conventional judicial proceeding" need not be exhausted before suing for damages under the CRA. Lane v. Wilson, supra at 274; Mitchell v. Wright, 154 F.2d 924, cert. denied, 329 U.S. 733 (1946).

136. N.Y. Times, June 1,1955 , p. 26 , col. 5 , reports that Georgia has set up a device whereby the superintendent of a county school system has authority to assign pupils to the schools they will attend. Students who object to this decision must appeal first to the superintendent, then to the local board of education, then to the state superintendent and then to the state board of education. 
a nature as to afford no real probability of relief. ${ }^{137}$ This exception to the rule should be applicable in the school discrimination situation whenever it appears that the school administration itself is intent on denying plaintiffs their rights. ${ }^{138}$

Another obstacle may exist in the rule of Snowden v. Hughes ${ }^{139}$ that sections 1983 and 1985(3) do not give a plaintiff the right to sue for a denial of equal protection unless he can demonstrate that he is a victim of a purposeful discrimination..$^{140}$ A requirement that defendants have the purpose to deny a citizen the equal protection of the laws is found in the wording of section 1985(3), but no similar phrase appears in section 1983.141 Nevertheless, Snowden and other decisions appear to have carried the requirement over into section 1983 where it has become a requirement of willfulness. ${ }^{142}$ It might be argued that whenever the deprivation to be remedied under 1983 is a denial of equal protection, rather than of due process, the imposition of the Snowden requirement is appropriate. But while the Supreme Court has construed the criminal sections of the CRA to require willfulness, ${ }^{143}$ there appears to be no reason why a similar requirement should be applied to section 1983 , which creates a civil liability sounding in tort. ${ }^{144}$ Even if willfulness is required under

137. "To remit each of these children and the thousands of others similarly situated to thousands of administrative hearings before this board to seek the relief to which the Supreme Court has said they are entitled would be a vain and useless gesture unworthy of a court of equity." Bush v. Orleans Parish School Bd., 24 U.S.L. WEeK 2388 (E.D. La. Feb. 15, 1956). Cf. Bruce v. Stilwell, 206 F.2d 554, 556 (5th Cir. 1953) ; Carter v. School Bd., 182 F.2d 531, 536 (4th Cir. 1950). See Davis, Administrative Law \& 189 (1951).

138. But cf. Mills v. Woods, 190 F.2d 201 (5th Cir. 1951) ; Cook v. Davis, 178 F.2d 595 (5th Cir. 1949). These were $\$ 1983$ suits in which injunctive relief against school discrimination was denied because plaintiffs had not exhausted their administrative remedies as required by state law. However, there was no allegation in either case that the administrative remedy was ineffectual.

139. 321 U.S. 1 (1944).

140. "The unlawful administration by state officers of a state statute fair on its face, resulting in its unequal application to those entitled to be treated alike, is not a denial of equal protection unless there is shown to be present in it an element of intentional or purposeful discrimination." Snowden v. Hughes, 321 U.S. 1, 8 (1944). In Snowden plaintiff sued for damages under $\$ \$ 1983$ and $1985(3)$. The Court upheld the lower court's dismissal of the complaint apparently because the failure to allege purposeful discrimination was a failure to allege a denial of equal protection. The court did not specifically indicate if it was only speaking of a requirement for suit under $\$ 1985(3)$.

141. Compare $\$ 1983$, quoted in note 111 supra, with $\$ 1985(3)$, quoted in note 121 stipra.

142. Snowden v. Hughes, 321 U.S. 1, 8 (1944); Glicker v. Michigan Liquor Control Comm'n, 160 F.2d 96 (6th Cir. 1947); Burt v. City of New York, 156 F.2d 791 (2d Cir. 1946) ; Morgan v. Null, 117 F. Supp. 11, 16 (S.D.N.Y. 1953).

Some courts also read a requirement of willfulness into the civil provisions of the Civil Rights Acts by assuming that the same requirement of the criminal provisions is controlling. See Boyer v. Garrett, 88 F. Supp. 353, 357 (D. Md. 1949), aff'd without considcration of this point, 183 F.2d 582 (4th Cir.), cert. denied, 340 U.S. 912 (1950). But sec note 144 infra and accompanying text.

143. See note 104 supra.

144. See Picking v. Pennsylvania R.R., 151 F.2d 240 (3d Cir. 1945), ccrt. denied, 332 U.S. 776 (1947). See also Note, 7 Baxlor L. Rev. 224, 230-32 (1955). 
section 1983, this need not inhibit and indeed recently has not inhibited the application of the statute. ${ }^{145}$ The opinion in Snowden stated that although a discriminatory purpose was not to be presumed, such purpose could be deemed apparent from the face of the conduct itself or could be proved by extrinsic evidence. ${ }^{140}$ Certainly, an allegation of purposeful discrimination cannot be said to be unsubstantiated if the discrimination proved is at all systematic. On its face, systematic discrimination should evince purposeful action.

The most serious substantive obstacle to the imposition of tort liability upon state officials lies in the doctrine of official immunity. ${ }^{147}$ The history and language of the Civil Rights Acts indicate that most, if not all, official immunities were meant to be rendered inoperative if state officials interfered with the Negro's Fourteenth Amendment rights. ${ }^{148}$ Nevertheless, a number of courts have recently indicated that the immunity doctrine was largely unaffected by the CRA. ${ }^{140}$ Absolute immunity under the CRA has been established for legislators and judges. ${ }^{150}$ Members of school boards and other administrative officials generally enjoy only a qualified common law immunity which is limited to actions taken in good faith. ${ }^{151}$ Under the CRA these officials are accorded at least no greater immunity, ${ }^{152}$ and it has been suggested that even good faith may not always be a defense. ${ }^{153}$ Whether or not common law immunity still

145. E.g., Flemming v. South Carolina Elec. \& Gas Co., 224 F.2d 752 (4th Cir. 1955) (abstracted at note 114 supra) ; McDonald v. Key, 224 F.2d 608 (10th Cir. 1955); Valle v. Stengel, 176 F.2d 697 (3d Cir. 1949); Westminster School Dist. v. Mendez, 161 F.2d 774 (9th Cir. 1947).

146. Snowden v. Hughes, 321 U.S. 1,8 (1944).

147. See Tate v. Arnold, 223 F.2d 782 (Sth Cir. 1955) (justice of the peace held to be immune from $\$ 1983$ damage suit); Note, The Doctrine of Official Immunity Under the Cizil Rights Acts, 68 Harv. L. Rev. 1229 (1955) ; Note, 46 Coluxr. L. Rev. 614 (1946).

148. See Picking v. Pennsylvania R.R., 151 F.2d 240 (3d Cir. 1945) ; Morgan v. Null, 117 F. Supp. 11, 12 (S.D.N.Y. 1953) ; Notes, 68 HaRv. L. Rev. 1229 (1955), 46 Colum. L. KEv. 614,618 (1946).

149. See, e.g., Tate v. Arnold, 223 F.2d 782 (Sth Cir. 1955) ; Francis v. Lyman, 216 F.2d 583, 588 (1st Cir. 1954); Dunn v. Estes, 117 F. Supp. 146 (D. Mass. 1953).

150. Tenney v. Brandhove, 341 U.S. 367 (1951) (legislator); Francis v. Crafts, 203 F.2d S09 (1st Cir. 1953) (judge); Tate v. Arnold, supra note 149 (justice of the peace).

151. E.g., Speyer v. School Dist. No. 1, 82 Colo. 534, 261 Pac. $\$ 59$ (1927) (officers of school district) ; see Cobb v. City of Malden, 202 F.2d 701, 706-07 (1st Cir. 1953) (concurring opinion); Prosser, TorTs 781 (2d ed. 1955); James, Tort Liability of Governmontal Units and Their Officers, 22 U. Crr. L. REv. 610, 635-48 (1955); Jennings, Tort Liability of Administrative Officers, 21 Mrnvs. L. Rev. 263, 276-97 (1937).

If school boards are considered sub-legislative bodies, their members might be absolutely immune, see Prosser, Torts 781 (2d ed. 1955), but this result is not certain, see Cobb v. City of Malden, supra.

152. See Cobb v. City of Malden, supra note 151, at 707: "The privilege by way of defense to the prima facie federal tort defined in [\$1983] . . should certainly be no broader than the privilege that would be accorded under the common law." See also Note, 6S HAnv. L. REv. 1229, 1235 (1955).

153. "Where [\$ 19\&3] ... has been invoked in situations which no doubt were a major concern of the Reconstruction Congress ... the Supreme Court has not been loath to impose tort liability upon such state officials... There it is no defense to the state officials 
applies to administrative officials may be of little importance when the damage suits against them are grounded on a denial of equal protection. Willfulness, as evidenced by systematic discrimination, will often be present in these suits, and willfulness is inconsistent with good faith.

The Civil Rights Acts will be useful in combatting indirect interference provided the circumvention device can be deemed state action. All of the CRA provisions except section 241 can usually be used only against persons acting under color of state law or, in other words, against state action. ${ }^{154}$ Most commentators agree that the establishment of private schools to replace the public schools, with provision for direct or indirect subsidization or control, will bring segregation by the new private schools within the present concept of state action under the Fourteenth Amendment. ${ }^{155}$ And a recent white primary case indicates that this segregation will constitute state action even if the state relinquishes all control and withdraws financial support. ${ }^{156}$

\section{ConcLusion}

No radical departure from existing law is necessary to utilize the contempt power and the Civil Rights Acts to enforce desegregation. The sanctions are available. What must be developed is a wise and farsighted plan for the careful use of these legal weapons. Vital to the success of any plan will be a federal agency capable of co-ordinating the use of the available enforcement devices. Before using its own criminal weapons, the agency should by negotiation at-

that they may have acted, not maliciously, but in the good-faith belief that they were performing their official duty under what they thought was valid state legislation." Francis v. Lyman, $216 \mathrm{~F} .2 \mathrm{~d} \mathrm{583,} 588$ (1st Cir. 1954). It is not clear on what basis the Supreme Court decisions referred to, Myers v. Anderson, 238 U.S. 368 (1915) and Lane v. Wilson, 307 U.S. 268 (1939), held that liability could be imposed on the election officials who were the defendants. It may have been, as the First Circuit suggests, because racial discrimination was involved, or because the defendants acted under a statute which ultimately was declared unconstitutional. For a discussion of the latter reason, see Field, The Effect of an Unconstitutional Statute in the Law of Public Officers: Liability of Officers for Action or Nonaction, 77 U. PA. L. Rev. 155 (1928) ; Rapacz, Protection of Officers Who Act Under Unconstitutional Statutes, 11 MrNw. L. Rev. 585 (1927).

154. 17 STAT. 13 (1871), 42 U.S.C. \$ 1983 (1952) refers to action under color of state law. See note 111 supra. Collins v. Hardyman, 341 U.S. 651 (1951), has construed 12 Stat. 284 (1861), 17 StaT. 13 (1871), 42 U.S.C. $\$ 1985$ (3) (1952), to punish only conspirators who act under color of law. 18 U.S.C. $\$ 242$ (1952) also refers to action under color of law, see note 96 supra, and this section has been held to reach acts done under color of federal as well as state law, Gowdy v. United States, 207 F.2d 730 (9th Cir. 1953).

155. See, e.g., Leflar \& Davis, Segregation in the Public Schools-1953, 67 Harv. L. REv. 377, 407 (1954); Nicholson, The Legal Standing of the South's School Resistance Proposals, 7 S.C.L.Q. 1, 62 (1954) : "The South's attempts to circumvent the school decision seem doomed to legal failure. The Court has ample theories to utilize in avoiding all circumvention proposals-ranging from the relatively simple state instrumentality concept to the all permeating doctrine of Shelley v. Kraemer"; Sutherland, Segregation by Race in the Public Schools-Retrospect and Prospect, 20 LAw \& ConTenP. ProB. 169, 183 (1955).

156. Rice v. Elmore, 165 F.2d 387 (4th Cir. 1947), cert. denied, 333 U.S. 875 (1948). 
tempt to convince resistant communities to desegregate in accord with district court mandates. If the use of sanctions becomes necessary, an over-all plan of enforcement should be formulated by the agency. Duplication of suits should be avoided. And the agency may prefer sporadic enforcement rather than the unleashing of the full force of the contempt power and the Civil Rights Acts.

An agency capable of co-ordinating enforcement presently exists within the Department of Justice. The Civil Rights Section of the Department now handles most of the actions brought under sections 241 and 242, and it has acquired considerable experience in the use of negotiation to avoid the need for suits to restrain and redress deprivations of civil liberties. ${ }^{157}$ The Section's staff should be expanded to enable it to prosecute 241, 242 and criminal contempt actions necessary to enforce desegregation. The Section would also be able to co-ordinate the use of private remedies by informal advice and aid to individuals and private civil liberties groups in connection with civil contempt proceedings and section 1983 and 1985(3) actions. The Justice Department's amicus curiae brief in the Brown case indicates its strong desire to end segregation in the public schools. ${ }^{168}$ It can make this desire a reality by using its own Civil Rights Section to supplement and co-ordinate the forces already mobilized to implement desegregation.

157. Putzel, Federal Civil Rights Enforcement: A Current Appraisal, 99 U. PA. L. Rev. 439, 445 (1951); Carr, Federal Protection of Civil Rights (1947).

158. See Brown v. Board of Education, 347 U.S. 483, 485 (1954). 